\title{
ANALISIS OMSET DAN POSISI BERSAING PADA KLASTER USAHA KECIL MENENGAH (UKM) SEPATU KOTA MOJOKERTO
}

\author{
Bahtiar Fitanto \\ Fakultas Ekonomi Universitas Brawijaya
}

\begin{abstract}
This articles describes about turnover and competitiveness position of footwear small and medium scale enterprises (sme's) at Mojokerto, East Java Province. SME's cluster approach is used to get the full maps of the ptroblem and policies that are needed. Development of small and medium scale enterprises is plays a crucial role for local economic development. This article is important because there are thousands offootwear small and medium scale enterprises in Mojokerto.
\end{abstract}

Keywords: small and medium scale enterprises, local economic development, cluster

\section{A. LATAR BELAKANG}

Kebanyakan negara berkembang mengandalkan pendekatan growth centre (pusat pertumbuhan) dan industri sebagai leading sector dalam strategi pembangunannya. Secara teoritik daerah pinggiran (periphery) akan berkembang melalui efek menyebar (spread effects) dan efek tetesan kebawah (trickle down effect). Tetapi pada kenyataannya, strategi ini tidak hanya gagal dalam menyebarkan dan merembeskan efek dari pusat-pusat pertumbuhan dan mempercepat proses transfromasi daerah pinggiran, tetapi justru kesenjangan sosial ekonomi semakin melebar.

Banyak para ahli yang kemudian mengemukakan bahwa perbedaan dalam pembentukan modal dan faktor input tidak banyak menjelaskan mengapa timbul perbedaan dalam pertumbuhan ekonomi (Kuncoro,1997). Hal ini selanjutnya menimbulkan pendapat bahwa ada banyak faktor yang tadinya dianggap "residual", ikut berperan dalam meningkatkan pertumbuhan ekonomi. Faktor residual yang dimaksud diantaranya adalah human investment dan kemajuan teknologi. Pentingnya human investment, yang menekankan pada peranan faktor pendidikan dan budaya, merupakan suatu tahapan awal menuju konsep pembangunan yang semakin tidak murni ekonomi lagi.

Pada sisi yang lain, perekonomian Indonesia rupanya menampakkan kemajuan yang membanggakan beberapa saat sebelum krisis yang lalu. Lihat saja, pembangunan infrastruktur yang fenomenal, ekspor sektor non migas yang meningkat tajam dan pertumbuhan ekonomi yang tinggi adalah beberapa contoh kemajuan yang patut mendapat pujian. Berbagai kemajuan ini telah membuat negara maju membuka mata kepada Indonesia sebagai negara raksasa yang siap bangun dan menjadi peta kekuatan baru dalam perekonomian dunia. Namun, krisis ini telah membuka mata kita akan banyaknya distorsi yang terjadi dalam perekonomian Indonesia. Perilaku perburuan rente (rent seeking behaviour) misalnya, merupakan salah satu contoh distorsi, yang disebabkan oleh kelemahan sistem perekonomian kita.

Seers (dalam Chaniago, 2001) menyatakan bahwa gagasan tentang pembangunan semakin mengakomodasi pentingnya martabat manusia dan kesejahteraan masyarakat sebagai tujuan pokok pembangunan. Maka, pembangunan tidak bisa dikatakan berhasil bila salah satu saja dari tiga hal, yaitu kemiskinan, pengangguran dan ketimpangan menjadi lebih buruk, meskipun pendapatan per kapitanya melambung tinggi. 


\section{Journal of Indonesian Applied Economics Vol. 3 No. 1 Mei 2009, 23-36}

Karya-karya Seers selanjutnya semakin mempertegas pemikirannya tentang pembangunan yang menitikberatkan pada masalah kesempatan kerja, pemerataan pendapatan dan memerangi kemiskinan. Dari segi ini, Seers dipandang sebagai ekonom negara maju pertama yang memasukkan aspek pembangunan manusia dan masyarakat ke dalam tujuan pembangunan.

Pada sisi yang lain, Malarangeng (2002) menjelaskan sejarah perekonomian yang sentralistis ini dimulai pada tahap pembangunan setelah apa yang disebutnya sebagai tahap pertama yang berlangsung pada 1966-1973. Dimana pada tahap pertama pembangunan Indonesia ini lebih diwarnai oleh kebijakan ekonomi yang mendesak untuk memperbaiki kinerja sistem perekonomian yang hancur akibat mekanisme "ekonomi revolusioner" era Presiden Soekarno.

Tahap kedua dari pembangunan di Indonesia menurut Malarangeng adalah tahun 1974 hingga awal 1980-an. Pada tahap ini kebijakan rehabilitasi dan liberalisasi parsial kaum teknokrat banyak menuai kritik dari para akademisi dan aktivis kemahasiswaan, dan puncak dari hal ini adalah meletusnya peristiwa Malari. Dari sini kebijakan sentralistis menjadi langkah utama dalam pembangunan di Indonesia.

Sejak 2001 Indonesia memasuki era desentralisasi dengan penekanan pada pembangunan ekonomi daerah yang semakin luas. Dan setiap upaya pembangunan ekonomi daerah bertujuan meningkatkan jenis dan jumlah peluang kerja (Arsyad, 2004:298). Pembangunan ekonomi daerah diera otonomi menghadapi berbagai tantangan baik internal maupun eksternal, seperti masalah kesenjangan dan iklim globalisasi, yang akhirnya menuntut tiap-tiap daerah untuk mampu bersaing di dalam dan luar negeri (Bappenas, 2004). Kesenjangan dan globalisasi berimplikasi kepada propinsi, kabupaten/kota untuk melaksanakan percepatan pembangunan ekonomi daerah melalui pengembangan ekonomi daerah berdasarkan potensi sektor unggulan yang dimiliki oleh masingmasing daerah.

Berkaitan dengan hal tersebut diatas, Usaha Mikro, Kecil, dan Menengah (UMKM) menempati posisi yang strategis untuk mempercepat perubahan struktural dalam rangka meningkatkan taraf hidup rakyat banyak, serta sebagai wadah kegiatan usaha bersama bagi produsen maupun konsumen. Pengembangan UMKM merupakan langkah strategis dalam meningkatkan dan memperkuat dasar kehidupan perekonomian sebagian besar rakyat Indonesia, khususnya dalam hal penyediaan lapangan kerja, mengurangi kesenjangan dan kemiskinan, mempercepat pemulihan ekonomi, serta memperkuat landasan pembangunan yang berkelanjutan dan berkeadilan berdasarkan sistem ekonomi kerakyatan. Dimana ekonomi kerakyatan dapat diartikan sebagai kegiatan ekonomi yang diselenggarakan oleh kebanyakan rakyat Indonesia dan pada umumnya terdiri atas koperasi, pengusaha mikro, pengusaha kecil dan menengah dalam rangka mewujudkan demokrasi ekonomi di Indonesia.

Pelaksanaan ekonomi kerakyatan lebih diarahkan pada upaya optimalisasi potensi setiap wilayah berdasarkan kondisi sumber daya alam, manusia, lingkungan, kreatifitas dan energi masyarakat yang bersangkutan. Pembangunan berbasis kerakyatan berarti pembangunan ekonomi yang berorientasi pada kesejahteraan rakyat dengan bertumpu pada pemberian kesempatan kerja seluasluasnya bagi masyarakat.

Namun dalam perkembangannya, UMKM masih belum menjalankan fungsi dan peranannya secara maksimal karena menghadapi berbagai kendala seperti masalah keterbatasan modal, teknik produksi, bahan baku, pemasaran, manajemen dan teknologi. Selain itu hambatan yang dihadapi oleh UMKM adalah keterbatasan dalam mengakses informasi pasar, keterbatasan jangkauan pasar, keterbatasan jaringan kerja, dan keterbatasan mengakses lokasi usaha yang strategis. Karena itu perlu dilakukan analisa untuk melihat faktor-faktor yang mempengaruhi posisi bersaing UMKM dan peran yang diembannya untuk meningkatkan daya saing daerah.

Tujuan penulisan artikel ini adalah untuk mengetahui gambaran profil usaha dan pengusaha sepatu di Kota Mojokerto. Selain itu artikel ini diterbitkan untuk mengetahui faktor-faktor yang mempengaruhi omset usaha dan posisi bersaing pada UMKM sepatu Kota Mojokerto serta menyusun pola pengembangan dan konsep peningkatan daya saing di UKM sepatu Kota Mojokerto. 


\section{B. KAJIAN TEORITIS}

\section{Konsep Pengembangan Ekonomi Lokal}

Pengembangan ekonomi lokal adalah upaya bersama antara pemerintah daerah, swasta dan kelompok masyarakat dalam mengelola sumber daya daerah. Pengembangan ekonomi lokal merupakan proses penataan kemitraan baru antara ketiga pihak tersebut, untuk merangsang pertumbuhan kegiatan ekonomi wilayah dan menciptakan lapangan pekerjaan. Secara alamiah, pengembangan ekonomi lokal selalu akan memperhatikan potensi dan kondisi sumber daya lokal, dalam kaitan usaha pemanfaatan aset ekonomi suatu daerah. Lembaga keuangan lokal milik masyarakat didukung oleh peran serta lembaga swadaya masyarakat umumnya diperlukan pula dalam rangka membantu pengelolaan dana pembangunan untuk pengembangan kegiatan ekonomi lokal yang mempunyai potensi kuat untuk tumbuh (klaster). Klaster dapat merupakan kegiatan ekonomi lokal yang sudah ada tetapi belum dikelola dengan baik maupun kegiatan ekonomi yang potensial tetapi belum digali secara optimal. Klaster diharapkan menjadi kegiatan ekonomi yang unggul secara kualitas, efisien di dalam berproduksi sehingga biaya produksi rendah, dan unggul dalam menguasai pasar sehingga produk yang dihasilkan mampu bersaing di pasar regional, nasional atau bahkan global. Selain itu, yang utama adalah mampu menyediakan kesempatan kerja luas yang berimplikasi pada peningkatan pendapatan masyarakat lokal serta mampu berperan di dalam proses peningkatan pendapatan wilayah.

Pengembangan kapasitas masyarakat merupakan upaya untuk meningkatkan pendapatan masyarakat lokal melalui kegiatan ekonomi produktif berbasis klaster yang berdaya saing. Klaster yang harus dikembangkan oleh suatu daerah, sebaiknya mempunyai ciri-ciri (source of advantage) sebagai berikut (Sumodiningrat, 2000) :

a. Comparative Advantage.

Berbasis potensi wilayah setempat (sumber daya alam) dan dapat berkembang secara baik di wilayah tersebut, sebagai sesuatu keunggulan komparatif yang dimiliki oleh wilayah bersangkutan, termasuk keunggulan dalam kemampuan sumber daya manusia.

b. Competitive Advantage

Mempunyai keunggulan kompetitive, berupa kemampuan usaha yang lebih baik dibandingkan dengan wilayah lain, termasuk kemampuan penguasaan teknologi, baik teknologi software (berupa manajemen) dan teknologi hardware (mesin produksi).

c. Institusional Advantage

Kedua keunggulan diatas, sebaiknya didukung oleh sistem kelembagaan yang kondusif bagi pengembangan klaster yang berdaya saing Dukungan sistem kelembagaan adalah sangat penting sebagai bentuk peran serta segenap pihak untuk mengembangkan kemampuan masyarakat lokal dalam melakukan kegiatan ekonomi produktif, baik dari unsur aparat (birokrasi dan suprastruktur) maupun masyarakat (dunia usaha dan lembaga swadaya masyarakat).

\section{UKM dan Pengembangan Ekonomi Rakyat}

Dalam pembangunan dibanyak daerah, kalau kita rujuk kepada visi dan misinya maka hampir seluruhnya berbicara tentang pengembangan ekonomi rakyat. Tetapi rupanya, misi ini masih banyak yang belum terlaksana seiring dengan sikap pemerintah yang masih belum menunjukkan keberpihakannya secara jelas kepada masyarakat kebanyakan, yaitu golongan ekonomi lemah. Kebijakan pemerintah yang dijalankan selama ini cenderung mengikuti alur teori ekonomi neoklasik konvensional, dimana krisis ekonomi Indonesia hanya akan pulih oleh pertumbuhan ekonomi yang tinggi. Pertumbuhan ini hanya dapat ditingkatkan kembali melalui investasi, dan investasi ini hanya akan mungkin jika program rekapitalisasi perbankan berjalan, yang artinya kredit para konglomerat harus dibantu dahulu dengan kredit baru agar perusahaannya dapat beroperasi lagi dan kita berharap, para konglomerat ini dapat kembali mengangsur hutang-hutangnya. 


\section{Journal of Indonesian Applied Economics Vol. 3 No. 1 Mei 2009, 23-36}

Pemberdayaan ekonomi rakyat ini terasa makin penting manakala kenyataan menunjukkan bahwa ekonomi Indonesia sebenarnya adalah berbasis ekonomi rakyat. Ekonomi rakyat (banyak) mencakup 90\% dari total jumlah unit usaha (business entity), menyediakan sekitar $80 \%$ kesempatan kerja, melakukan lebih dari $65 \%$ kegiatan distribusi, dan melakukan kegiatan produksi bagi sekitar $55 \%$ produk dan jasa yang dibutuhkan masyarakat, serta keberadaannya tersebar merata di seluruh Indonesia (Krisnamurthi, 2002). Hanya saja ketimpangan distribusi aset produktif -yang sekitar 65\%nya dikuasai oleh $1 \%$ pelaku usaha besar- menyebabkan kontribusi nilai produksi (GDP) dan ekspor kegiatan ekonomi rakyat relatif lebih kecil.

Ramli (dalam Kuncoro, 1997) mengambarkan struktur perekonomian kita bagai sebuah piramida. Dimana pucuk piramida tersebut dikuasai oleh para pengusaha besar, dengan beroperasi pada struktur pasar quasi-monopoli oligopolistik, hambatan masuk (barrier to entry) yang tinggi, menikmati margin keuntungan yang luar biasa tinggi dengan akumulasi modal yang cepat. Dimana dibagian bawah piramida berkerumun usaha skala kecil dan menengah dengan iklim yang sangat kompetitif, hambatan masuk yang rendah, serendah marjin keuntungannya dan dengan tingkat drop out yang tinggi. Struktur semacam ini terbukti mencuatkan isu konsentrasi dan konglomerasi, serta menguatkan dualisme perekonomian nasional.

Dialektika hubungan ekonomi yang terjadi menampakkan banyak penduduk yang menggantungkan hidupnya dari "ekonomi rakyat" berada dalam posisi tertindas dalam konstelasi perekonomian nasional. Ada kecenderungan terjadinya konsentrasi oleh pengusaha-pengusaha besar (monopoli-oligopoli) dan membentuk kolaborasi dalam penguasaan ekonomi. Salah satu penyebabnya adalah penguasaan industri dari hulu sampai ke hilir. Pada akhirnya, kebijakan-kebijakan yang diambil oleh pemerintah meniadakan peran yang jelas bagi ekonomi rakyat. Keadaan inilah yang menjadi paradoksal dari kebijakan yang dilakukan oleh pemerintah.

Rachbini (2001) menegaskan bahwa seharusnya Usaha Kecil dan Menengah tidak perlu meminta perlakukan khusus untuk bisa berkembang dengan baik, tetapi yang lebih utama dan terpenting adalah menuntut perlakuan yang adil sehingga akses terhadap pasar dan sumber-sumber ekonomi yang ada bisa dimanfaatkan oleh semua pelaku ekonomi secara efisien. Maka, ekonomi kerakyatan yang tepat adalah dibangun diatas pondasi mekanisme pasar yang sehat, bukan yang distortif. Sehingga permasalahan yang lebih krusial sejatinya adalah fairness atau keadilan dalam pasar.

Unsur fairness ini menurut Rachbini (2001) adalah unsur yang terpenting (pertama) dalam mengembangkan ekonomi kerakyatan. Unsur penunjang selanjutnya antara lain adalah kedua, mekanisme pasar yang independen dari kekuasaan sehingga pasar tidak dipakai oleh negara dan kalangan tertentu saja untuk berburu rente ekonomi, ketiga, pengelolaan sumberdaya alam dan lahan yang berkeadilan. Sedangkan unsur keempat, demokratisasi hubungan pekerja dengan perusahaan dalam keseimbangan bargaining position yang terbaik bagi keduanya, dan terakhir, kelima, penciptaan sistem lembaga keuangan yang transparan dan memberi ruang yang terbuka bagi usaha kecil dan menengah.

\section{Klaster UKM dan Pengembangan Daya Saing Daerah}

Salah satu aspek yang mononjol dalam pembangunan di Indonesia sebelum era krisis lalu adalah peningkatan yang pesat peran sektor-sektor industri manufaktur dengan dibarengi penurunan yang relatif dari sektor pertanian. Hasil studi Basri, Ikhsan dan Saleh (Basri, 1995) menunjukkan bahwa dengan studi pola normal ala Chenery, perkembangan industri manufaktur di Indonesia cenderung mengejar pola normalnya semenjak 1983. Tetapi, dalam periode yang sama justru peranan industri berat menurun dan industri ringan sebaliknya. Padahal biasanya pematangan industrialisasi lazim ditandai dengan peningkatan peran industri berat dan penurunan peran industri ringan. Disamping itu, penurunan pangsa sektor pertanian dalam Produk Domestik Bruto lebih cepat dari pola normalnya.

"Daya saing" merupakan istilah yang memiliki pengertian dengan konsep multidimensi. Perlu dipahami bahwa dari perspektif mikro, meso dan makro ekonomi, istilah daya saing memiliki pengertian yang sebenarnya berbeda, namun saling berkaitan. 
Hal penting lain adalah bahwa pergeseran/perkembangan teori/konsep terkait dengan daya saing, tidaklah semata memberikan pengayaan pengertian konsep/teori (dan dukungan empiris), tetapi juga berimplikasi pada pergeseran/perubahan paradigma. Bagaimana penyikapan pelaku ekonomi terhadap hal ini justru sering menjadi "pembeda" keberhasilan peningkatan daya saing, baik dalam konteks perusahaan, industri ataupun negara/daerah.

Dalam pembangunan ekonomi yang esensinya adalah meningkatkan kesejahteraan masyarakat yang semakin tinggi dan semakin adil, maka peningkatan daya saing merupakan suatu agenda utama yang tidak mungkin diabaikan. Namun mungkin ada "banyak" cara untuk itu. Keberhasilan banyak pihak (negara-negara yang dinilai berhasil dalam pembangunan ekonominya) menunjukkan bahwa suatu pendekatan "baru" telah membawa kepada keberhasilan tersebut, walaupun ini bukan berarti pendekatan yang akan secara seketika membawa kepada keadaan tersebut. Ini merupakan (dan memerlukan) rekonseptualisasi dalam pembangunan ekonomi daerah.

Di era global semacam ini dibutuhkan industri yang tangguh dan kompetitif. Hanya industri yang demikianlah yang dapat menciptakan pertumbuhan ekonomi, menciptkan lapangan pekerjaan, meningkatkan pendapatan masyarakat dan dapat mengurangi angka kemiskinan. Dibutuhkan investasi untuk membangun industri yang kuat. Ironisnya investasi tidaklah tumbuh dengan baik. Pertumbuhan ekonomi kita pasca krisis yang ditopang oleh konsumsi rumah tangga yang menyumbang $80 \%$. Proporsi investasi dari GDP hanya $20 \%, 10 \%$ lebih rendah dari tingkat sebelum krisis.

\section{METODE PENELITIAN DAN ANALISIS DATA}

Penelitian ini akan menganalisa tentang posisi bersaing Usaha Mikro, Kecil, dan Menengah (UMKM) untuk mendukung pengembangan daya saing dan pemasaran daerah. Lokasi penelitian adalah di Kota Mojokerto. Jenis penelitian adalah explanatory research (penelitian penjelasan), karena penelitian ini membahas hubungan antar variabel penelitian dan menguji hipotesis yang telah dirumuskan sebelumnya dengan fokus terletak pada penjelasan hubungan antar variabel (Singarimbun dan Effendi, 1995).

Teknik analisis yang digunakan adalah: a.) Analisis statistik deskriptif, dimana analisis dilakukan untuk mendapatkan gambaran/deskripsi dari setiap variabel yang diteliti dengan menggunakan distribusi frekuensi, mean (rata-rata), dan persentase (\%). b.) Analisis statistik inferensial, digunakan untuk menguji hipotesis penelitian yang telah ditetapkan dengan menggunakan sampel yang ada. Dalam penelitian ini menggunakan regresi karena akan dilihat pengaruh variabel bebas terhadap variabel terikat, baik secara simultan maupun parsial.

\section{1). Analisis Omset Usaha}

Variabel yang digunakan adalah:

a. $\quad$ Variabel Dependen (Y): Omset

b. Variabel Independen (X): Tenaga kerja, Modal, Network, Koperasi dan Harga.

Dari variabel tersebut, spesifikasi model adalah sebagai berikut :

Omset $=\beta_{0}+\beta_{1}$ Tenaga kerja $+\beta_{2}$ Modal $+\beta_{3}$ Network $+\beta_{4}$ Koperasi $+\beta_{5}$ Harga $+\mathrm{e}$

Keterangan:

- Omset menunjukkan nilai penjualan dalam satu tahun dalam jutaan rupiah.

- Tenaga kerja menunjukkan jumlah tenaga kerja yang diserap oleh perusahaan.

- Modal menunjukkan nilai modal awal yang digunakan untuk memulai usaha dalam jutaan rupiah.

- Network menunjukkan keunggulan dalam jaringan usaha, yang diberi skor 5 (sangat kuat), 4 (kuat), 3 (sedang), 2 (lemah) dan 1 (sangat lemah).

- Koperasi menggunakan variabel dummy, dimana $1=$ anggota koperasi dan $0=$ bukan anggota koperasi. 


\section{Journal of Indonesian Applied Economics}

Vol. 3 No. 1 Mei 2009, 23-36

- Harga menunjukkan keunggulan harga dalam persaingan, yang diberi skor 5 (sangat kuat), 4 (kuat), 3 (sedang), 2 (lemah) dan 1 (sangat lemah).

- Error (e) menunjukkan variabel pengganggu.

\section{2). Analisis Posisi Bersaing Perusahaan}

Variabel yang digunakan adalah:

a. $\quad$ Variabel Dependen (Y): Posisi

b. Variabel Independen (X): Inovasi, Kualitas, Loyalitas, Respon, Harga, Koperasi, Badan hukum dan SDM

Dari variabel spesifikasi model adalah sebagai berikut:

Posisi Bersaing $=\beta_{0}+$ Inovasi + Kualitas + Loyalitas + Respon + Harga + Koperasi + Badan Hukum + SDM + e

Keterangan:

- Posisi menunjukkan posisi perusahaan dalam persaingan, yang diberi skor 5 (sangat kuat), 4 (kuat), 3 (sedang), 2 (lemah) dan 1 (sangat lemah).

- Inovasi menunjukkan kemampuan perusahaan melakukan inovasi/pengembangan produk, yang diberi skor 5 (sangat kuat), 4 (kuat), 3 (sedang), 2 (lemah) dan 1 (sangat lemah).

- Kualitas menunjukkan fokus strategi perusahaan pada kualitas, yang diberi skor 5 (sangat kuat), 4 (kuat), 3 (sedang), 2 (lemah) dan 1 (sangat lemah).

- Loyalitas menunjukkan seberapa jauh loyalitas konsumen terhadap produk/merk perusahaan, yang diberi skor 5 (sangat kuat), 4 (kuat), 3 (sedang), 2 (lemah) dan 1 (sangat lemah).

- Respon menunjukkan kemampuan perusahaan dalam merespon perubahan, yang diberi skor 5 (sangat kuat), 4 (kuat), 3 (sedang), 2 (lemah) dan 1 (sangat lemah).

- Harga menunjukkan keunggulan harga dalam persaingan, yang diberi skor 5 (sangat kuat), 4 (kuat), 3 (sedang), 2 (lemah) dan 1 (sangat lemah).

- Koperasi menggunakan variabel dummy, dimana $1=$ anggota koperasi dan $0=$ bukan anggota koperasi.

- Badan hukum menggunakan variabel dummy, dimana $1=$ sudah berbadan hukum dan $0=$ belum berbadan hukum.

- SDM menunjukkan keunggulan berupa tenaga kerja yang terlatih, yang diberi skor 5 (sangat kuat), 4 (kuat), 3 (sedang), 2 (lemah) dan 1 (sangat lemah).

- Error (e) menunjukkan variabel pengganggu.

\section{HASIL DAN PEMBAHASAN}

\section{Potensi Industri Persepatuan Kota Mojokerto}

Industri persepatuan Kota Mojokerto berjumlah 309 UKM persepatuan (Disperindag, 2003). Dengan jumlah sebesar ini, maka akan sangat krusial untuk dilakukan program pengembangan terhadap kegiatan UKM ini. Apalagi mengingat permasalahan dalam industri persepatuan ini sangat kompleks, terutama sekali karena penetrasi produk luar dengan harga yang sangat bersaing membuat para pelaku di industri ini menghadapi permasalahan yang sangat besar.

Realita yang terjadi saat ini, terjadi penurunan pada penjualan produk sepatu. Hal ini ditengarai karena persaingan yang tajam dengan produk sepatu China. Secara umum, sebenarnya produk sepatu lokal masih diminati oleh masyarakat. Hanya saja, produk China harus diakui memiliki banyak variasi baik model, trend, dan bahan bakunya serta teknisnya/teknologi produksinya.

Persaingan justru terjadi dengan ketat karena tampilannya produk-produk lokal bermerk (branded) yang merambah segmen pasar produk home industry. Kelemahan Indonesia secara umum (dibidang persepatuan) adalah tidak mampu memproduksi bahan baku sesuai tuntutan global secara kualitas. Di pasar Eropa dan Amerika, masyarakat menuntut produk yang bahan bakunya bebas 
dari unsur-unsur kimia yang membahayakan, baik bagi tubuh dan lingkungan (daur ulang), China lagi-lagi sudah mencapai dua level diatas kita dalam hal berproduksi bahan-bahan bakunya sesuai tuntutan negara-negara maju tersebut.

Pasar diluar kedua benua tersebut, memang tidak ketat menuntut hal-hal seperti itu, tetapi mereka mengalihkan pembeliannya pada China yang memang 30\%-40\% harganya lebih murah. Pasar ekspor dewasa ini amat berat untuk ditembus jika bersaing dengan produk China.

Melihat apa yang telah tersebutkan diatas, maka para pengrajin sepatu di Kota Mojokerto selanjutnya berhimpun, dengan nama Komite Eksekutif Persepatuan Kota Mojokerto dengan harapan, para pengrajin ini dapat menghadapi secara bersama-sama persoalan yang mendera. Dengan bekerja dan berprogram bersama, diharapkan dapat memunculkan berbagai program terobosan agar mampu meningkatkan daya saing dan mengatasi berbagai hambatan berusaha. Pembentukan Komite Eksekutif Persepatuan Kota Mojokerto ini sendiri telah mendapatkan pengakuan dari Walikota Mojokerto dengan diterbitkannya Surat Pengakuan Walikota Mojokerto No. 050/618/417.403/2004 tentang Pembentukan Komite Eksekutif Persepatuan Kota Mojokerto pada tahun 2004.

\section{Identitas Usaha}

Dari hasil survei yang telah dilakukan, diketahui bahwa Industri sepatu di Mojokerto merupakan industri rumah tangga yang dicirikan oleh lokasi usaha sama dengan lokasi tempat tinggal. Dari 98 responden yang diteliti, seluruhnya $(100 \%)$ adalah industri rumah tangga. Selain itu juga dilihat dari jenis usahanya, industri ini merupakan milik perorangan / sendiri (99\%) dan hanya 1 usaha sampel yang merupakan kerjasama.

Dari sisi umur pemilik usaha sepatu rata-rata berada pada masa produktif. Pemilik usaha berumur antara $36-40$ tahun $(39,80 \%), 28$ orang berumur antara $41-50(28,58 \%), 23$ orang berumur antara 26 - 35 tahun $(23,47 \%)$, dan hanya 1 orang yang berumur dibawah 25 tahun $(1,02 \%)$, sedangkan pemilik usaha yang berumur diatas 51 tahun berjumlah 7 orang $(7,14 \%)$, hal ini mengindikasikan bahwa pemilik usaha sepatu memiliki usia yang produktif yang tentunya akan sangat berpengaruh pada keberlangsungan usaha khususnya dalam proses inovasi dan pengembangan usaha dimasa yang akan datang.

Dari 98 sampel usaha sepatu yang diteliti sebagian besar $(69,4 \%)$ usahanya belum berbadan hukum. Menurut status usahanya, sebanyak 30 atau 30,6\% sampel usaha sudah berbadan hukum sedangkan sisanya belum berbadan hukum. Hal ini sesuai dengan karakteristik industri kecil yang pada umumnya belum berbadan hukum. Sebagian besar usaha sepatu bukan merupakan anggota koperasi yaitu sebesar $82,7 \%$ dari total sampel penelitian, sedangkan sisanya sebesar $17,3 \%$ merupakan anggota koperasi.

\section{Permodalan}

Dilihat dari sisi besarnya Modal awal, usaha sepatu memiliki berbeda satu sama lain. Sebagian besar modal awal sepatu adalah dibawah Rp.5000.001,- atau sebesar 52,04\%, selanjutnya usaha dengan modal Rp.15.000.001 - Rp. 25.000 .000 berjumlah 26 usaha (26,53\%). Meskipun besarnya modal awal usaha ini didominasi dengan nilai nominal dibawah Rp. 25.000.000,- akan tetapi ada juga usaha yang memiliki modal awal lebih dari Rp. 55.000 .000 yaitu sebanyak 8 usaha $(8,16 \%)$.

Sumber modal awal tersebut ada yang berasal dari modal sendiri maupun pinjaman dari pihak lain. Sumber modal sebagian besar usaha sepatu berasal dari pinjaman $(90,8 \%)$ yang berasal dari bantuan modal lunak Disperindag, perbankan, koperasi, toko bahan baku, rekanan, keluarga, teman bahkan ada juga dari renternir (1 usaha). Sedangkan sumber modalnya dari pribadi/modal sendiri sebanyak $9,2 \%$ dari seluruh sampel yang diteliti.

\section{Omset Pertahun}

Dari 98 sampel usaha yang diteliti, omset pertahun dari usaha sepatu, minimal omset pertahun adalah sebesar Rp. 6.146.250, dengan nilai rata-rata sebesar Rp. 22.7105.192,35, sedangkan penjualan pertahun yang tertinggi adalah sebesar Rp. 1,2 milyar. 


\section{Journal of Indonesian Applied Economics Vol. 3 No. 1 Mei 2009, 23-36}

Sebanyak 57 usaha sepatu atau 58,16\% memiliki omset diatas Rp. 120.000.000,- hal ini menunjukan bahwa usaha ini mempunyai prospek yang baik dan menguntungkan. Omset pertahun antara Rp. 100.000.000 - 120.000.001 dan Rp. 60.000.001 - 80.000.001 terdapat 10 usaha atau sebesar $10,20 \%$ dari total sampel yang diteliti. Selanjutnya untuk omset pertahun antara Rp. 40.000.001 - 60.0000.000,- dan Rp. 80.000.001 - 100.000.000,- masing-masing sebesar 7,14\% dan 6,12\%. Sedangkan sisanya dibawah Rp. 40.000 .001 sebesar 4,16\%.

\section{Administrasi Usaha}

Sebagian besar usaha sepatu telah melakukan pembukuan keuangannya yaitu sebesa 95 usaha (96.9\%) sedangkan sisanya 3 usaha $(3,1 \%)$ belum melakukan pembukuan keuangannya. Dari segi laporan posisi keuangan perusahaan menunjukan bahwa sebesar $62,2 \%$ terdapat laporan keuangan dan sisanya sebesar $37,8 \%$ belum ada laporan posisi keuangannya.

\section{Profil Tenaga Kerja}

Jumlah tenaga kerja keseluruhan dari 98 sampel usaha yang diteliti adalah sebanyak 985 orang, yang kebanyakan berasal dari desa sendiri dan kota Mojokerto, dimana dalam proses rekruitmen tenaga kerja dilakukan berdasarkan tes kerja maupun langsung merekrut saudara sendiri, tetangga dan kenalan.

Dalam proses kegiatan usaha seperti produksi, distribusi dan pemasaran, dimana $53,1 \%$ usaha telah melakukan pembagian kerja secara jelas sedangkan sisanya sebesar $46,9 \%$ belum melakukannya. Dari jumlah keseluruhan tenaga kerja dari usaha yang menjadi sampel penelitian, hanya 604 tenaga kerja yang melakukan pembagian tenaga kerja secara jelas.

Pembagian kerja secara jelas tersebut dibagi menjadi 3 bagian yaitu bagian produksi, distribusi dan pemasaran. Dari keseluruhan tenaga kerja yang memperoleh pembagian kerja secara jelas, tenaga kerja bagian produksi produksi memiliki proporsi terbesar yaitu 393 orang $(65,07 \%)$, diikuti oleh bagian distribusi dan pemasaran masing-masing-masing-masing sebesar 106 orang (17,55\%) dan 105 orang $(17,38 \%)$.

Dari sisi pendidikan tenaga kerja, sebanyak 410 orang $(41,62 \%)$ dari total tenaga kerja adalah berpendidikan sekolah dasar, 303 orang $(30,76 \%)$ berpendidikan sekolah menengah tingkat pertama, 270 orang $(27,41 \%)$ berpendidikan sekolah menengah atas dan hanya 2 orang $(0,20 \%)$ berpendidikan perguruan tinggi. Tingginya pekerja yang berpendidikan rendah sangat mudah dipahami karena industri sepatu hanya memerlukan keahlian dan bakat serta tenaga untuk memproduksi produknya (sepatu). Dalam upaya meningkatkan kemampuan dan skill dalam memproduksi sepatu, sebagian besar usaha tidak melakukan pelatihan yaitu sebesar $83,7 \%$ sedangkan sisanya sebesar $16,3 \%$ melakukan pelatihan.

Dari usaha sampel yang sering mengikuti pelatihan (16 usaha), diketahui frekuensi pelatihan terbesar dilakukan rata-rata satu kali dalam setahun $(10,2 \%)$ sedangkan sebanyak $6(6,1 \%)$ usaha mengikuti pelatihan rata-rata satu kali dalam sebulan.

Pelatihan yang dilakukan diselenggarakan oleh Dinas Perindustrian dan Perdagangan (Disperindag), IFSC Sidoarjo, Dinas Koperasi, PK dan M, Pemerintah Kota Mojokerto dan ada juga yang melakukan pelatihan secara mandiri. Hasil survey menunjukan berbagai manfaat dari mengikuti pelatihan yaitu sebagai berikut :

- Membantu kelancaran produksi

- Menambah wawasan seluk beluk usaha

- Menambah wawasan desain dan jaringan usaha dan Kontrol kualitas kerja (produksi)

- Menambah wawasan produksi (studi banding)

- Menambah kreatif desain manajemen

- Memperluas jaringan usaha

- Menambah pemahaman dunia usaha dan mempelancar kreativitas produksi 
- Melihat tingkat kemampuan dalam berproduksi

- Tenaga kerja tidak sembrono dalam berproduksi

\section{Produksi}

Dari hasil survey diketahui bahwa seluruh usaha sepatu tidak mengalami kesulitan dalam memperoleh bahan baku. Pasokan bahan baku diperoleh dari Surabaya, mojokerto, Sidoarjo, Magetan dan beberapa daerah lainnya.

Dalam upaya mempertahankan keberlangsungan usahanya, setiap usaha sepatu diperlukan pengembangan produk agar tetap eksis dan bersaing dipasar. Dari hasil survey diperoleh bahwa seluruh usaha telah melakukan pengembangan produknya. Ada beberapa cara yang dilakukan usaha sepatu di Mojokerto dalam upaya mengembangkan produknya diantaranya adalah sebagai berikut:

- Mengikuti trend pasar, peningkatan mutu produksi dan inovasi desain

- Variasi model dan bahan baku, penggunaan tenknologi informasi

- Membuat model baru, merubah model yang laku di pasar

- Mengikuti perkembangan pasar dari sales,

- Mencontoh model, merubah model lama

- Membuat contoh, meniru merk terkenal yang laku di pasaran

- Melakukan pecah model, mencontoh model yang terlaris dipasaran

- Menambah accessories produk, membuat model baru yang laku di pasar

Dalam upaya pengembangan produk tentunya usaha harus bisa merespon keinginan/selera konsumen. Dari hasil survey terhadap 98 usaha yang menjadi sampel penelitian diperoleh informasi bagaimana cara usaha merespon selera konsumen. Cara yang biasa digunakan diantaranya adalah sebagai berikut:

- $\quad$ Peningkatan mutu dan desain

- Mengikuti tren, peningkatan informasi dari rekanan usaha, pesanan model (desain) trend pasar

- Pameran-pameran, brosur ke instansi/pasar, peningkatan mutu produksi dan desain

- Mengikuti basar (pasar rakyat), promosi ke toko dan grosir, peningkatan mutu dan desain

- Membuat contoh produk

- Mengikuti trend pasar, melayani pesanan pasar, penambahan accessories

- Meningkatan kualitas produksi, pengerjaan tepat waktu, penawaran langsung ke konsumen

- Pengerjaan sesuai dengan pesanan

Selain pengembangan produk, hal yang paling utama dalam upaya menjaga kualitas produk adalah adanya kontrol terhadap kualitas produk. Hasil survey menunjukan bahwa seluruh usaha telah melakukan kontrol kualitas produk. Upaya mengontrol kualitas produk oleh usaha sepatu dilakukan dengan cara sebagai berikut:

- Pengawasan melekat pada bahan baku, proses produksi dan produksi akhir

- Pengawsan secara bertahap, pengawasan bahan baku, pengawasan produksi, pengawasan ahkir produksi

- Seleksi kualitas produk, pengawalan ketat bahan baku, pengawalan ketat finishing

- Pengawasan seleksi produksi, pengawasan proses produksi, pengawasan proses akhir dan packing (kemasan)

- Ada bagian finishing/tukan ranut, control jahitan, control pengeleman/ perakitan

- Pengontrolan pada proses produksi, pengontrolan pada bahan baku, pengontrolan pada pengeleman 
- $\quad$ Tes hasil produksi (kekuatan), kontrol proses produksi

\section{Pemasaran}

Faktor yang paling berperan dalam proses pemasaran adalaha ketersediaan jaringan usaha untuk memasarkan produknya. usaha sepatu di Mojokerto yang diteliti, hampir seluruhnya memiliki jaringan usaha yaitu sebesar 97 usaha $(99,0 \%)$ dan hanya 1 usaha yang tidak mempunyai jaringan.

Beberapa lembaga yang merupakan jaringan usaha tersebut diantaranya: Pemkot (Mojokerto,Malang, Bojonegoro), Industri , PLN Jakarta, Disperindag, Dinas koperasi, IFSC Surabaya, grosir-toko, industri-industri, sekolah-sekolah, koperasi karyawan, kontraktor, toko bahan baku, toko/grosir pasar Turi, Pasar Patrang, Kudus, Solo, dan lain sebagainya. Sedangkan daerah yang meliputi jaringan usaha yang dimiliki yaitu: Dalam Kota, Antar Provinsi (Jatim, Jateng, Jabar), Luar Pulau (kalimantan, ambon, maluku, Ujung Pandang, Bali), Kota Mojokerto, Sidoarjo, Surabaya, Solo, Yogyakarta, Malang, Jember, Banyuwangi, Bandung, Magetan, Jakarta, Tuban, Tulungagung dan Kudus, bahkan ada juga yang sampai ke Luar negeri (Eropa).

Dalam proses penjualan hasil produksi sepatu, kebanyakan usaha menggunakan pedagang perantara untuk memasarkan produknya. Sebanyak 83 usaha $(84,7 \%)$ menggunakan pedagang perantara untuk memasarkan produknya, sedangkan sisanya sebesar 53 usaha $(15,3 \%)$ tidak mempergunakan pedagang perantara. Pedagang perantara yang dimaksud diantaranya adalah koperasi, karyawan pabrik, karyawan instansi, perorangan, Disnaker (Ambon, Madura, Jogyakarta, Surabaya, Surakarta, Mojokerto), toko dan grosir, sales keliling, kontraktor-karyawan instansi pemerintah, pedagang pasar, karyawan instansi pemerintah dan non pemerintah, distributor, perorangan (rekanan dagang), sales (tenaga pemasaran free lance) dan teman produsen/pengusaha serta pelanggan tetap. Dimana hampir sebagian besar usaha mempunyai pelanggan tetap $(95,9 \%)$ sedangkan sisanya $(4,1 \%)$ tidak mempunyai pelanggan tetap.

Dalam upaya meningkatkan kemampuan tenaga kerja khususnya bidang pemasaran, sebanyak 64 usaha $(65,3 \%)$ tidak melakukan pelatihan kontinyu kepada tenaga pemasaran, sedangkan sebanyak 34 usaha $(34,7 \%)$ melakukan pelatihan secara kontinyu. Dari pelatihan kontinyu yang dilakukan, sebanyak 32 usaha $(32,7 \%)$ melakukan pelatihan tenaga pemasaran sebanyak 1x perbulan dan hanya 2 usaha $(2,0 \%)$ yang melakukannya setiap $2 x$ dalam satu bulan, sedangkan sisanya sebanyak 64 usaha $(65,3 \%)$ tidak pernah melatih tenaga pemasarannya secara kontinyu.

Meskipun sebagian besar tenaga pemasaran jarang diikutkan dalam pelatihan secara kontinyu namun hampir seluruh sampel penelitian menyatakan bahwa tenaga pemasaran sangat berguna, yang dikemukakan oleh 95 usaha $(96,9 \%)$ sedangkan sisanya sebanyak 3 usaha $(3,1 \%)$ menyatakan tidak berguna. Ada beberapa alasan yang menyebutkan bahwa tenaga pemasaran sangat berguna atau diperlukan diantaranya karena:

- Dapat memperluas pasar dan menambah info pasar

- Dapat memperluas jaringan produk

- Dapat menjaga kelangsungan produksi

- Dapat memperbesar (meningkatkan) produksi

- Menyebabkan pemasaran produk lebih merata dan luas

- Mengakibatkan hasil produk lebih cepat dikenal oleh masyarakat dan lebih tahu tentang selera pasar 


\section{CLUSTER SEPATU MOJOKERTO}

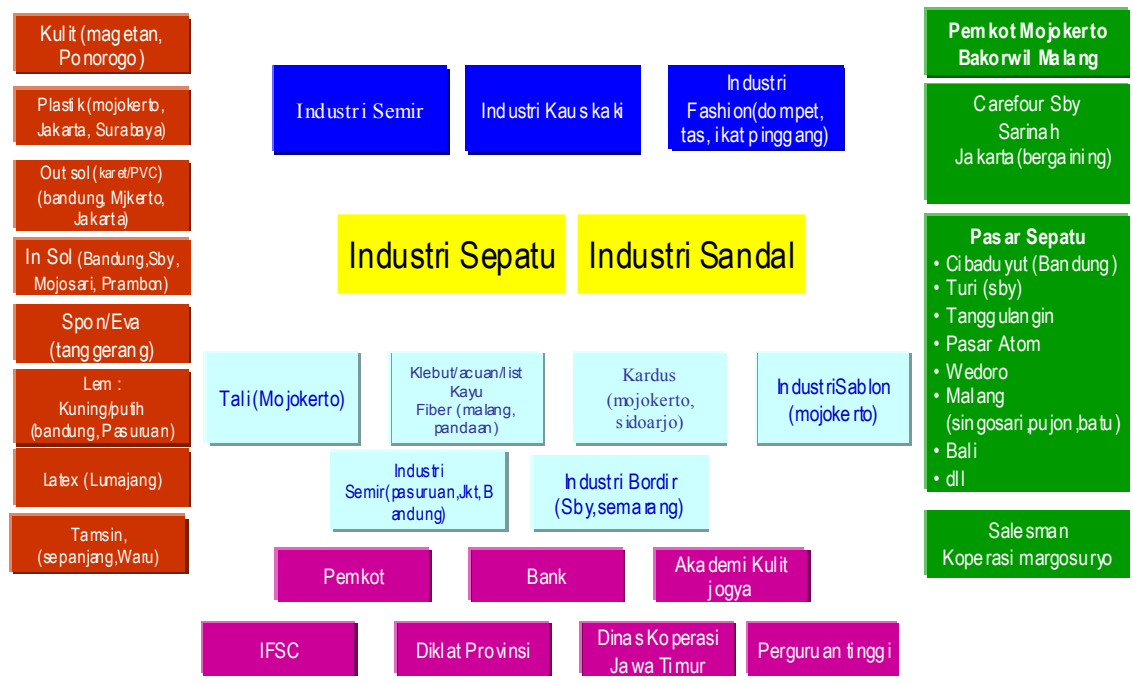

Sumber: Hasil FGD Klaster Industri Sepatu Kota Mojokerto

Gambar 1. Klaster Sepatu Mojokerto

\section{Analisis Keunggulan Usaha}

Kemajuan sebuah usaha akan sangat tergantung dari karakteristik usaha dan keunggulan yang dimiliki. Keunggulan yang pertama adalah keunggulan pemasaran. Hal ini menjadi sangat penting karena pemasaran yang baik akan mempermudah penetrasi terhadap pasar yang pada akhirnya akan sangat berpengaruh terhadap penjualan. Semakin baik tenaga pemasaran yang ada akan berbanding lurus dengan kenaikan omset yang diperoleh. Berdasarkan hasil survey diperoleh informasi bahwa usaha sepatu Mojokerto lemah dalam keunggulan tenaga pemasaran yaitu sebesar $76,5 \%$ dari total sampel yang diteliti. Untuk usaha yang mempunyai keunggulan tenaga pemasaran yang sedang dan kuat masing-masing berjumlah 16 dan 6 usaha sedangkan yang sangat lemah tenaga pemasarannya hanya 1 usaha.

Keunggulan tenaga pemasaran akan sangat mempengaruhi proses penjualan produk yang ditawarkan ke pasar. Kemapanan tenaga pemasaran akan membuka suatu jaringan baru untuk melakukan ekspansi produknya. Keunggulan jaringan usaha akan sangat berpengaruh pada jumlah produk yang dipasarkan, semakin luas jaringan usaha maka akan semakin besar juga produk yang dijual. usaha sepatu di Mojokerto sebagian besar memiliki keunggulan jaringan yang sedang berdasarkan survey yang telah dilakukan. Hal ini diindikasikan oleh jawaban responden ( usaha), dimana 79 usaha $(80,6 \%)$ memiliki keunggulan jaringan sedang, 10 usaha $(10,2 \%)$ lemah, 8 usaha $(8,2 \%)$ kuat dan hanya 1 usaha $(1,0 \%)$ memiliki keunggulan jaringan sangat lemah.

Selain keunggulan jaringan usaha, faktor keunggulan harga akan sangat berpengaruh terhadap keberhasilan usaha. Keunggulan harga akan sangat berkaitan dengan efisiensi produksi yang telah dilakukan. Semakin efisien dalam memproduksi suatu barang maupun jasa maka harga produk yang ditawarkan akan semakin kompetitif.

Sebagian besar usaha sepatu dalam hal keunggulan harga masih menunjukan keadaan yang sedang $(83,7 \%), 10,2 \%$ dan 1,0\% menunjukan keunggulan harga masih lemah dan sangat lemah. Sedangkan usaha yang memiliki keunggulan harga yang kuat hanya sebesar $5,1 \%$ atau hanya 5 usaha. Selain keunggulan harga, faktor lain yang mempengaruhi produk dapat diterima pasar atau tidak adalah kemampuan pengusaha dalam mengembangkan produknya atau dengan kata lain kemampuan berinovasi. 


\section{Journal of Indonesian Applied Economics \\ Vol. 3 No. 1 Mei 2009, 23-36}

Kemampuan inovasi usaha sepatu menunjukan kondisi yang sedang, yaitu sebesar 76,5\%, 15,3\% lainnya menunjukan kondisi yang lemah dan sangat lemah. Sedangkan sebanyak 8 usaha sepatu $(8,2 \%)$ menunjukan kondisi yang kuat.

\section{Analisis Kinerja Industri Sepatu}

Keberhasilan sebuah organisasi dalam mengelola sumber daya yang dimiliki untuk menghasilkan output yang maksimal sangat tergantung pada evaluasi kinerja yang dilakukan oleh manajemen suatu organisasi tersebut. Carley (dalam Mardiasmo, 2002:298), mendefinisikan pengukuran kinerja sebagai suatu usaha guna mentaksir (memperkirakan) penerimaan layanan didalam suatu bentuk kuantitatif.

Dalam penelitian ini kinerja industri sepatu di Mojokerto akan dianalisis melalui analisis keunggulan usaha, omset usaha dan posisi bersaing. Analisis keunggulan usaha dilakukan melalui deskripsi hasil penilian kuisioner, sedangkan untuk omset usaha dan posisi bersaing digunakan analisis regresi berganda dengan metode OLS (Ordinary Least Square). Model yang digunakan dalam penelitian ini mengadaptasi model yang digunakan Mudrajad Kuncoro (1998) tentang pengembangan industri pedesaan.

\section{Analisis Omset Usaha}

Omset usaha merupakan salah faktor yang mempengaruhi kinerja suatu usaha dilihat dari sudut mikro. Faktor - faktor yang diduga mempengaruhi omset usaha adalah tenaga kerja, modal perusahaan, jaringan usaha (networking), modal, keanggotaan koperasi, dan harga.

Variabel-varibel yang berpengaruh secara signifikan terhadap omset industri sepatu di Mojokerto adalah: tenaga kerja, modal dan keunggulan jaringan usaha. Keseluruhan variabel tersebut berkoefisien positif, yang menunjukan bahwa adanya pengaruh positif variabel tersebut terhadap omset. Semakin tinggi jumlah tenaga kerja maka akan semakin tinggi pula omset yang akan diperoleh. Begitu pula semakin tinggi jumlah modal awal dan keunggulan jaringan usaha yang dimiliki maka akan semakin tinggi pula omset usaha.

Dari beberapa variabel yang diuji dalam model, hanya dua variabel yang tidak berpengaruh secara signifikan yaitu variabel koperasi dan harga yang ditunjukan oleh angka t statistik yang tidak signifikan pada derajat keyakinan 5\%. Dengan demikian menjadi anggota maupun tidak menjadi anggota koperasi tidka berpengaruh kepada omset, begitu pula dengan keunggulan harga yang tidak berpengaruh terhadap omset. Meskipun begitu, kedua variabel tersebut tidak dapat dihilangkan, karena nilai $\mathrm{F}$ statistik yang signifikan mengindikasikan bahwa semua variabel independen secara bersama-sama berpengaruh terhadap omset yang dicapai oleh industri sepatu di Mojokerto.

\section{Analisis Posisi Bersaing}

Eksis atau tidaknya suatu usaha sangat ditentukan oleh posisi bersaing usaha tersebut dalam pasar. Semakin kuat posisi bersaing semakin tinggi pula kinerja usaha dalam indutri tersebut. Faktor-faktor yang diduga mempengaruhi posisi bersaing adalah kemampuan inovasi produk, srategi usaha pada kualitas, respon terhadap perubahan, keunggulan harga, loyalitas konsumen, status usaha, keanggotaan koperasi, keunggulan tenaga pemasaran dan peranan pedagang perantara.

Hasil estimasi membuktikan bahwa variabel utama yang berpengaruh secara signifikan terhadap posisi bersaing adalah kemampuan inovasi (INOVASI), fokus stretegi kualitas (KUALITAS), loyalitas konsumen (LOYALITAS), respon terhadap perubahan (RESPON) dan keunggulan tenaga pemasaran (SDM) dengan nilai signifikansi dibawah 5\%. Sedangkan varibel lainnya seperti, keunggulan harga (Harga), keanggotaan koperasi (KOPERASI), berbadan hukum (BHUKUM) dan pedagang perantara (PERANTARA) tidak berpengaruh secara signifikan terhadap posisi bersaing industri sepatu.

Seluruh koefisien variabel yang berpengaruh terhadap posisi bersaing memiliki tanda positif yang berarti bahwa semakin tinggi kemampuan inovasi, fokus strategi usaha, loyalitas konsumen, respon terhadap perubahan dan keunggulan tenaga pemasaran akan semakin kuat juga posisi 
bersaingnya. Sedangkan tidak signifikannya variabel harga menunjukan bahwa harga tidak dapat dijadikan tumpuan keunggulan bersaing industri. Demikian juga mengenai keanggotaan koperasi, ternyata tidak mempunyai peran berarti bagi terciptanya posisi bersaing yang kuat. Hal ini tidaklah mengherankan karena industri sepatu di Mojokerto sebagian besar bukan merupakan anggota koperasi. Sama halnya dengan status usaha yang berbadan hukum maupun tidak serta pemanfaatan pedagang perantara bukan hal yang mempengaruhi kuatnya posisi bersaing. Akan tetapi keempat variabel yang tidak berpengaruh tersebut tidak dapat dihilangkan dari model karena secara bersamasama seluruh variabel independen yang dimasukan mempengaruhi posisi bersaing seperti yang ditunjukan oleh nilai statistik F yang signifikan.

\section{E. KESIMPULAN DAN REKOMENDASI}

1. UKM adalah sektor ekonomi yang sangat potensial untuk dikembangkan di daerah. UKMUKM ini telah menjadi ikon yang mampu untuk mendongkrak daya saing daerah melalui kekhasannya,. Bahkan tak jarang potensi ini menjadi pembeda antara daerah yang satu dengan daerah yang lain.

2. UKM yang ada di daerah seringkali merupakan potensi-potensi yang berangkat melalui faktor sumberdaya yang tersedia banyak di daerah tersebut. Dengan demikian sebenarnya UKM dapat mendayagunakan potensi ekonomi di sekitarnya untuk berkembang. Dalam hal ini membutuhkan kebijakan pemerintah untuk bijak dalam menyikapi permasalahan potensi daerah. Misalnya, kasus UKM sepatu ini yang sedang menghadapi serbuan produk China.

3. Variabel-varibel yang berpengaruh secara signifikan terhadap omset UKM sepatu di Mojokerto adalah: tenaga kerja, modal dan keunggulan jaringan usaha. Sedangkan variabel utama yang berpengaruh secara signifikan terhadap posisi bersaing adalah kemampuan inovasi, fokus stretegi kualitas, loyalitas konsumen, respon terhadap perubahan dan keunggulan tenaga pemasaran.

4. Pemetaan potensi ekonomi melalui pendekatan klaster akan membantu daerah untuk menemukenali siapa mitra dan siapa pesaing bagi pengembangan potensi daerahnya. Sekaligus pemetaan potensi ini akan memudahkan bagi pemerintah daerah untuk melihat perasalhan-permasalahan UKM secara jernih, karena permasalahan UKM dengan produk yang berbeda akan berbeda pula kebutuhan dan tantangannya.

5. Dengan klaster, akan terbentuk sebuah energi kemitraan yang kuat dengan melibatkan berbagai pihak dengan kesamaaan kepentingan untuk mendayagunakan potensi ekonomi dalam mendongkrak daya saing.

\section{DAFTAR PUSTAKA}

Adi, Isbandi Rukminto, 2002, Pemikiran-pemikiran dalam Pembangunan Kesejahteraan Sosial, Lembaga Penerbit Fakultas Ekonomi Universitas Indonesia, Jakarta.

Arsyad, Lincolin, 1983, Pengantar Perencanaan Ekonomi, Edisi 1, Media Widya Mandala, Yogyakarta.

Barus, Sedia Willing (ed), 2002, Strategi Memajukan Usaha Kecil dan Menengah, Pustaka Sora Mido, Jakarta.

Bendavid, Val Avron, 1991, Regional and Local Economic Analysis for Practititoners, Preegers, New York.

Blakely, Edward, J, 1994, Planning Local Economic Development, SAGE Publication, $2^{\text {nd }}$ edition. Chaniago, Andrianof A., 2001, Gagalnya Pembangunan: Kajian Ekonomi Politik Terhadap Akar 
Journal of Indonesian Applied Economics

Vol. 3 No. 1 Mei 2009, 23-36

Krisis Indonesia, Cetakan Pertama, LP3ES, Jakarta.

Glasson, John, 1977, Introduction to Regional Planning, The Anchor Press Limited.

Hafsah, Mohammad Jafar, 1999, Kemitraan Usaha: Konsep dan Strategi, Sinar Harapan, Jakarta.

Harham, Robert Q dan Banasick, Shawn, 1999, Shift Share Analysis and Changes in Japanese Manufacturing Employment, Growth and Change, Vol 31, 108-123, Blackwell Publisher UK.

Kadariah, 1985, Ekonomi Perencanaan, Penerbit FE-UI, Jakarta, Cetakan V.

Kuncoro, Mudrajat, 1998, Pengembangan Industri Pedesaan Melalui Koperasi dan Usaha Kecil: Suatu Studi Kasus di Kalimantan Timur, Analisis CSIS, Tahun XXVI No. 1, Januari-Februari 1997.

Kuncoro, Mudrajat, 2002, Analisis Spasial dan Regional: Studi Aglomerasi dan Kluster Industri Indonesia, UPP AMP YKPN, Yogyakarta.

Mallarangeng, Rizal, 2002, Mendobrak Sentralisme Ekonomi, Terjemahan Martin Aleida, Cetakan Pertama, Kepustakaan Populer Gramedia, Yayasan Adikarya IKAPI dan Ford Foundation, Jakarta.

Munir, Badrul, 2002, Perencanaan Pembangunan Daerah dalam Perspetif Otonomi Daerah, Bappeda Propinsi NTB.

Partomo, Titik Sartika dan Abd. Rachman Soejoedono, 2002, Ekonomi Skala Kecil/Menengah dan Koperasi, Ghalia Indonesia, Jakarta.

Fitanto, Bahtiar dan Risfan Munir, 2003, Panduan Penyusunan Modul Pengembangan Ekonomi Lokal Partisipatif, Kerjasama Pemerintah RI, USAID dan RTI.

Porter, Michael, 1998, Clusters and the New Economics of Competition, Harvard Business Review, Nov-Dec, Boston.

Rachbini, Didik J., 2001, Ekonomi di Era Transisi Demokrasi, Cetakan Pertama, Ghalia Indonesia, Jakarta.

Richardson, Harry W, 1981, Dasar-dasar Ilmu Ekonomi Regional, Lembaga Penerbit FE-UI, Jakarta. 